Masry, F. L. G. (1952). J. gen. Microbiol. 7, 201-210

\title{
Production, Extraction and Purification of the Haemagglutinin of Haemophilus pertussis
}

\author{
BY F. L. G. MASRY* \\ The Lister Institute of Preventive Medicine, Elstree, Hertfordshire
}

SUMMARY: Most, though not all, freshly isolated strains of Haemophilus pertussis contain haemagglutinin. When organisms are grown on solid medium the haemagglutinin is associated with the cell. In liquid cultures the haemagglutinin in the early stages of growth is also associated with the cell but later diffuses into the medium.

Haemagglutinin can be extracted by sodium chloride or sodium acetate from H. pertussis grown on solid medium. It can be precipitated from the extracts by methanol in the cold and resuspended in phosphate buffer. Precipitation by methanol gives a considerable degree of purification.

Haemagglutinin deteriorates rapidly on storage even at low temperatures. The rate of deterioration is less with solutions in $50 \%$ glycerol. Fowl red blood cells or stromata absorb the haemagglutinin but not the toxin. The sodium chloride extract also contains agglutinogen but the sodium acetate extract does not.

Antihaemagglutinin can be prepared by immunizing rabbits with haemagglutinin either in the form of extracts or bacterial suspensions. The most potent antisera are obtained using as antigen red blood cells saturated with haemagglutinin.

Mice infected either intracerebrally or intranasally with $\boldsymbol{H}$. pertussis cannot be protected either by active immunization with haemagglutinin or by passive immunization with antihaemagglutinin.

It was shown by Keogh \& North (1948) that the supernatant fluids from liquid cultures of Haemophilus pertussis contained haemagglutinin and were able to produce active immunity in mice to experimental pertussis infection. Although these fluids undoubtedly contained other soluble products of the organism, in addition to haemagglutinin, the authors were of the opinion that the protection induced was related to the haemagglutinin content. This opinion was supported by the results of passive protection tests, in which the protective potency of $\boldsymbol{H}$. pertussis antisera was shown to be a direct function of their antihaemagglutinin content. The work reported in this communication was made to verify these conclusions and to clarify the relationship of haemagglutinin to other recognized antigens of $\boldsymbol{H}$. pertussis such as the agglutinogen and the toxin.

\section{MATERIALS AND METHODS}

The haemagglutinin test. A modification of the Keogh \& North method was used. Fowl blood was collected aseptically in $3 \%$ sodium citrate and the red blood cells (R.B.C.) washed 3 times with 6 vol. of normal saline. For the test $1 \%$ R.B.c. suspension in saline was used. Twofold dilutions in saline of the haemagglutinin preparation were made in $2 \times 0.5 \mathrm{in}$. tubes using $0 \cdot 2 \mathrm{ml}$. volumes. To each dilution $0.2 \mathrm{ml} .1 \%$ R.B.c. suspension was added, the

* Present address : Department of Bacteriology, Faculty of Medicine, Alexandria, Egypt. 
mixtures thoroughly shaken, incubated at $37^{\circ}$ and the end-points read after $1 \mathrm{hr}$. according to the patterns of the sedimented cells using Salk's method (1944). Saline was used throughout as diluent. No improvement in the test was obtained with other diluents such as saline with added cysteine as recommended by Keogh \& North, Casamino acids, Lock's solution or 0.2Mphosphate buffer. The temperature of $37^{\circ}$ at which haemagglutinin and R.B.c. were incubated was not critical; other temperatures such as $4,18,45$ and $50^{\circ}$ were found to be equally satisfactory and gave the same titres as the tests done at $37^{\circ}$.

Strains and media. Strains of $H$. pertussis were obtained from the first subculture of the original swabs taken from cases of pertussis. They were maintained in the freshly isolated condition by drying from the frozen state.

The Bordet-Gengou (B.G.) medium used contained $33 \%$ defibrinated horse blood and $1 \%$ Proteose Peptone Difco. No improvement in haemagglutinin production was obtained with medium containing a higher concentration of blood.

The liquid medium was prepared according to the method used by Cohen \& Wheeler (1946).

\section{HAEMAGGLUTININ IN CULTURES}

Solid medium. Strains were tested for their ability to produce haemagglutinin by titrating suspensions from the $24 \mathrm{hr}$. growth at $36^{\circ}{ }_{\mathrm{i}}$ ion B.G. The suspensions were standardized to contain $10,000 \times 10^{6}$ organisms/ml. against Brown's tubes assuming $H$. pertussis to be equivalent to $H$. influenzae. No difference was found in the haemagglutinin titre of suspensions prepared from 24, 48, 72 or $96 \mathrm{hr}$. growth. This result was not in agreement with the findings of Ungar (1949), who was probably working with a different type of haemagglutinin system.

Table 1. The haemagglutinin content of 120 strains of Haemophilus pertussis in their second or third subculture on B.G. medium

$\left.\begin{array}{rrr}\text { Titre } & \overbrace{\text { No. }} \text { Strains } & \% \\ 16 & 14 & 11 \cdot 6 \\ 8 & 22 & 18 \cdot 3 \\ 4 & 10 & 8 \cdot 3 \\ 2 & 32 & 26 \cdot 6\end{array}\right\} 65 \%$ positive

The titres in the Tables $1-4$ and 7 are given as the reciprocal of the highest dilution of suspension or extract which gave complete haemagglutination.

The haemagglutinin titres of 120 strains in their second or third subculture are shown in Table 1. It is evident that there was considerable variation in titre; some strains produced no haemagglutinin while others gave a titre of 1/16. It was also found that the rate of fall in titre with progressive subculture was not the same for all strains. These results are in agreement with those of Standfast $(1951 a, b)$. The ability of strains to produce haemagglutinin was 
not related to their agglutinogen content, as measured by the agglutinating titre against smooth $H$. pertussis antisera prepared in a rabbit; some strains with high agglutinogen content had no detectable haemagglutinin. Neither was there a correlation between haemagglutinin and the capsulation of the organism (Lawson, 1940), as both haemagglutinin and non-haemagglutinin producing strains proved to be capsulated.

Liquid medium. A typical experiment showing the relation of haemagglutinin production to the growth of $\boldsymbol{H}$. pertussis in liquid medium is shown in Fig. 1 . Similar results to this were obtained with three different strains and are in

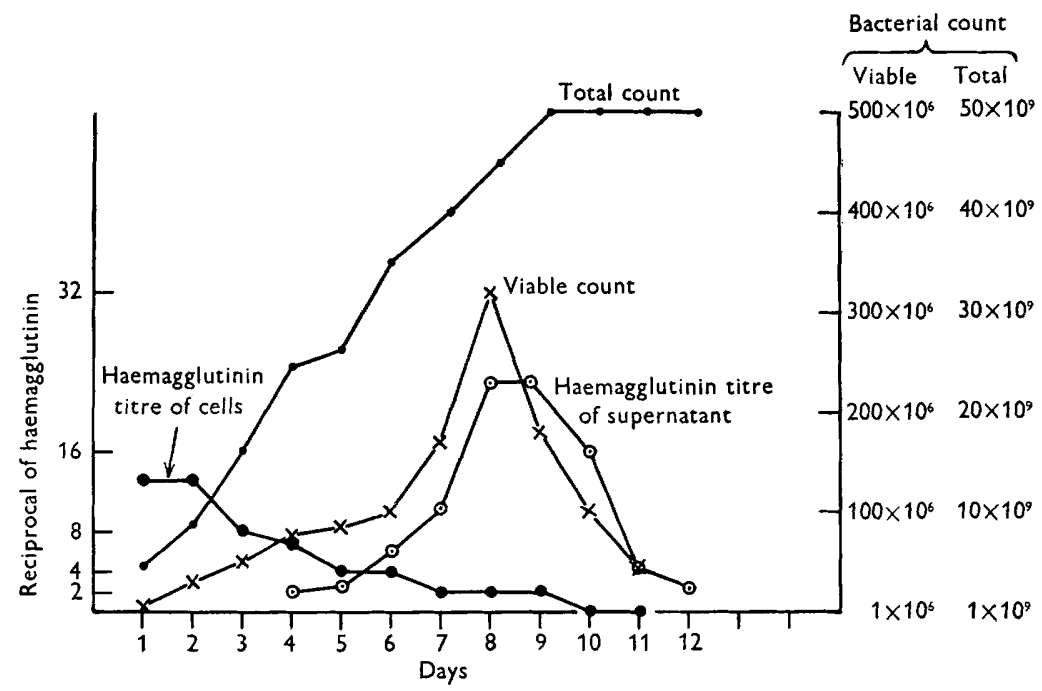

Fig. 1. Relation of haemagglutinin production to growth curves of $\boldsymbol{H}$. pertussis.

agreement with those of Fisher(1948). Haemagglutinin was found to be present in the bacterial cells during the early stages of growth and thereafter gradually decreased. On the other hand, the supernatant fluid contained in the early stages of growth little or no haemagglutinin but showed increasing titres after the $3 \mathrm{rd}$ or 4 th days until a maximum was reached on the 8 th day. This increase was followed by a rapid decline, probably due to the medium becoming alkaline.

Although a number of methods (Table 2) was used in attempts to extract haemagglutinin from $H$. pertussis only two gave extracts with high titre. These are described in detail.

Extraction with $\mathrm{NaCl}$. Strains of high haemagglutinin content were grown on в.G. and harvested after $24 \mathrm{hr}$. The growth was suspended in $2 \mathrm{~m}$-sodium chloride to a density of $4 \times 10^{10}$ organisms $/ \mathrm{ml}$. and incubated at $37^{\circ}$ for $48 \mathrm{hr}$. The suspension was then centrifuged at $0^{\circ}$ at $3000 \mathrm{r} . \mathrm{p} . \mathrm{m}$. and the supernatant fluid separated from the deposit. The haemagglutinin titre of the fluid was on the average 1/128. This procedure was arrived at after investigating the effect of extraction with saline concentrations ranging from 0.5 to $2.5 \mathrm{M}$ for periods from 8 to $48 \mathrm{hr}$. at 0,18 and $37^{\circ}$. It is evident 
from Tables 3 and 4 that $2 \mathrm{M}$-saline for $48 \mathrm{hr}$, at $37^{\circ}$ gave the greatest yield. It was also shown that at temperatures higher than $37^{\circ}$ less haemagglutinin was extracted, probably on account of its thermolability. Washing the organisms with saline or water, or grinding the dry organisms in a mortar before extraction did not increase the yield of haemagglutinin in the extract.

Table 2. Methods used in attempts to extract haemagglutinin

from $\mathbf{H}$. pertussis

\begin{tabular}{llc}
\multicolumn{1}{c}{ Method } & \multicolumn{1}{c}{$\begin{array}{c}\text { Average } \\
\text { Author }\end{array}$} & $\begin{array}{c}\text { Avaemagglutinin } \\
\text { titre of extract }\end{array}$ \\
Water & Flosdorf \& Kimball (1940) & $<2$ \\
$\mathbf{0 . 8 5 \%}$ saline & Katasampes et al. $(1942)$ & $<2$ \\
NaOH & Miller (1934) & $<2$ \\
Urea & Hink \& Johnson (1947) & $<2$ \\
HCl & Smolens \& Mudd (1943) & 8 \\
Freezing and thawing & Evans \& Maitland (1937) & $\mathbf{8}$ \\
Grinding with alumina & McIlwain (1948) & $<\mathbf{2}$ \\
2M-NaCl & Murray (1929) & $\mathbf{1 2 8}$ \\
M-sodium acetate & Masry & $\mathbf{1 2 8 - 2 5 6}$
\end{tabular}

Table 3. Titre of supernatant fluids of $\mathbf{H}$. pertussis after extraction with $\mathrm{NaCl}$ at $37^{\circ}$

$\begin{array}{clrccc}\begin{array}{c}\text { Time of } \\ \begin{array}{c}\text { extraction } \\ (\text { hr. })\end{array}\end{array} & 0.5 \mathrm{M} & 1.0 \mathrm{M} & 1.5 \mathrm{M} & 2.0 \mathrm{M} & \mathbf{2 . 5 \mathrm { M }} \\ 8 & <2 & <2 & <2 & <2 & <2 \\ 18 & <2 & 4 & 4 & 16 & 8 \\ 24 & 2 & 4 & 8 & 64 & 16 \\ 48 & 4 & 4 & 32 & 128 & 32\end{array}$

Table 4. Titre of supernatant fuids of $\mathrm{H}$. pertussis after extraction with $2 \mathrm{M}$-sodium chloride

$\begin{array}{ccr}\begin{array}{c}\text { Temperature of } \\ \text { extraction }\end{array} & \begin{array}{c}\text { Time of } \\ \text { extraction (hr.) }\end{array} & \text { Titre } \\ 0^{\circ} & 8 & <2 \\ & 18 & 8 \\ & 24 & 32 \\ 18^{\circ} & 48 & 64 \\ & 8 & <2 \\ & 18 & 8 \\ 37^{\circ} & 24 & 32 \\ & 48 & 128 \\ & 8 & <2 \\ & 18 & 8 \\ & 24 & 64 \\ & 48 & 256\end{array}$

Extraction with sodium acetate and precipitation with methanol. The extraction of haemagglutinin by sodium acetate was investigated by varying the conditions of extraction as in the sodium chloride extraction. The most potent extracts were obtained with $\mathrm{M}$-sodium acetate at $37^{\circ}$ for $48 \mathrm{hr}$. with an 
optimal density of $8 \times 10^{10}$ organisms $/ \mathrm{ml}$. The titre of haemagglutinin in the extract was on the average $1 / 128$ to $1 / 256$. Haemagglutinin could be extracted from organisms which had been washed with saline or distilled water, and this was a point of practical importance as large-scale production involved the harvesting of organisms from Roux bottles by flooding the growth off the surface of the medium.

Haemagglutinin was precipitated from the sodium acetate extracts by methanol, a method used by Pillemer (1946) and Pillemer, Toll \& Badger (1947) for the purification of diphtheria and tetanus toxins, and by Robbins \& Pillemer (1950) for precipitating the protective fraction from $H$. pertussis. The sodium acetate extract was cooled to $-3^{\circ}$ and the $\mathrm{pH}$ adjusted to be slightly acid. Methanol chilled to $-18^{\circ}$ was added slowly (about $2 \mathrm{ml} . / \mathrm{min}$.) with constant stirring, and the temperature of the mixture maintained at $-5^{\circ}$ throughout. The final concentration of methanol was $40 \%$ by volume. The mixtures were allowed to remain at $-10^{\circ}$ overnight and were then centrifuged at $-10^{\circ}$ for 1 hr. at 5000 r.p.m. The supernatant fluid was removed and the precipitate resuspended in distilled water at $2^{\circ}$ and dried from the frozen state. The dry material was readily soluble in $0 \cdot 5 \mathrm{M}$-phosphate buffer at $\mathrm{pH} 6 \cdot \mathbf{8}$.

This method brought about a considerable degree of purification of the haemagglutinin. Before methanol precipitation, extracts with a titre of $1 / 128$ to $1 / 256$ contained an average of $0.7 \mathrm{mg}$. N/ml., and after precipitation solutions of the precipitates with the same titre contained only $0 \cdot 02-0 \cdot 03 \mathrm{mg}$. $\mathrm{N} / \mathrm{ml}$.

\section{PROPERTIES OF HAEMAGGLUTININ}

Antigenicity of haemagglutinin. Rabbits immunized with haemagglutinin, in the form of either extract or bacterial suspension, produced antihaemagglutinin, the potency of which was titrated by determining the dilution of antiserum necessary to neutralize 10 minimal haemagglutinin units (m.h.u.). One haemagglutinin unit was taken as the minimal amount of a solution of haemagglutinin which produced complete agglutination of $0.2 \mathrm{ml}$. of $0.5 \%$ suspension of fowl R.B.C. It was immaterial which haemagglutinin preparation was used for the titration of antisera. Titrations made with the supernatants from 8-day fluid cultures, sodium chloride extracts, sodium acetate extracts and solutions of the methanol precipitate, gave the same titre of antihaemagglutinin for any one serum. The haemagglutinin in all four preparations therefore appeared to be antigenically the same.

Agglutinogen content of extracts. The sodium chloride and sodium acetate extracts were tested for agglutinogen by a method similar to that used by Flosdorf \& Kimball (1940). H. pertussis antiserum with high agglutinin titre was absorbed with extract and the extent of the absorption determined by titrating the agglutinins before and after absorption. Each of five different antisera were absorbed with each of the two extracts in varying dilutions, and typical results with one serum are given in Table 5 . The sodium chloride extract when undiluted decreased the agglutinin titre of the serum from $1 / 25,600$ to $1 / 3200$ and even with extract diluted $\frac{1}{2}$ and $\frac{1}{4}$ the titre was decreased to $1 / 6400$. On the other hand, the sodium acetate extract even 
undiluted had no effect on the agglutinin titre. This result indicated that the sodium chloride extract contained agglutinogen but that the sodium acetate extract did not. Support for these findings was obtained by immunizing rabbits with each extract; antisera prepared against the sodium chloride extract had an agglutinating titre of $1 / 4000$ but no agglutinins were detected in antisera prepared against the sodium acetate extract.

Table 5. Adsorption of agglutinin from $\mathrm{H}$. pertussis antiserum by haemagglutinin extracts

\begin{tabular}{|c|c|c|c|c|c|c|}
\hline \multicolumn{2}{|c|}{ Absorbent } & \multicolumn{5}{|c|}{ Dilution of antibacterial serum } \\
\hline Type & Concentration & 3,200 & 6,400 & 12,800 & 25,600 & 51,200 \\
\hline & None & ++ & ++ & ++ & \pm & 0 \\
\hline $\begin{array}{l}\text { Sodium chloride } \\
\text { extract }\end{array}$ & $\begin{array}{c}\text { Undiluted } \\
1: 2 \\
1: 4 \\
1: 8 \\
1: 16\end{array}$ & $\begin{array}{l} \pm \\
+ \\
+ \\
+t \\
+t\end{array}$ & $\begin{array}{c}0 \\
\pm \\
+ \\
++ \\
++\end{array}$ & $\begin{array}{c}0 \\
0 \\
0 \\
+ \\
++\end{array}$ & $\begin{array}{l}0 \\
0 \\
0 \\
\pm \\
\pm\end{array}$ & $\begin{array}{l}0 \\
0 \\
0 \\
0 \\
0\end{array}$ \\
\hline $\begin{array}{c}\text { Sodium acetate } \\
\text { extract }\end{array}$ & $\begin{array}{c}\text { Undiluted } \\
\qquad \begin{array}{l}1: 2 \\
1: 4 \\
1: 8 \\
11: 16\end{array}\end{array}$ & $\begin{array}{l}++ \\
++ \\
++ \\
++ \\
++\end{array}$ & $\begin{array}{l}++ \\
++ \\
++ \\
++ \\
++\end{array}$ & $\begin{array}{c}+ \\
++ \\
+ \\
++ \\
++\end{array}$ & $\begin{array}{l} \pm \\
0 \\
\pm \\
+ \\
\pm\end{array}$ & $\begin{array}{l}0 \\
0 \\
0 \\
0 \\
0\end{array}$ \\
\hline
\end{tabular}

Toxicity of extracts. The toxicity of three haemagglutinin preparations was tested: the sodium chloride extract, the sodium acetate extract and the methanol precipitated material. Tests were made by both the intradermal injection of rabbits and the intravenous injection of mice using solutions each with a haemagglutinin titre of 1/128. Each extract was toxic. The intradermal injection produced necrotic lesions, similar to those described by Evans \& Maitland (1937) for the thermolabile toxin of $H$. pertussis, and intravenous injection proved lethal. The potency of the toxin in the extracts was not however similar and, as each extract had the same haemagglutinin titre, it was concluded that the toxic and haemagglutinin factors were different. This conclusion was confirmed, for it was shown that $10 \%$ washed R.B.c. when mixed with extracts and incubated for $1 \mathrm{hr}$. at $37^{\circ}$ completely absorbed the haemagglutinin but not the toxin. A similar separation was achieved using stromata.

Thermolability. Haemagglutinin reconstituted in $\mathbf{0 \cdot 2}$ M-phosphate buffer $\mathrm{pH} 6.8$ to give a titre of $1 / 128$ was titrated after it had been incubated at various temperatures for different periods. Complete loss occurred within a few minutes at $60^{\circ}$, after $72 \mathrm{hr}$. at $37^{\circ}$ and after 4 days at room temperature. Storage at $4^{\circ}$ caused the titre to fall $25 \%$ in 2 weeks and after 35 days no haemagglutinin was detected. Storage at $-10^{\circ}$ did not prevent deterioration; in 60 days the activity was completely lost.

Effect of preservatives. The rate of deterioration of haemagglutinin was not influenced by the addition of either $\mathbf{0 . 3} \%$ formalin, $0.5 \%$ phenol or $1 / 10,000$ 
thiomersalate. Glycerol, however, was found to retard the rate of deterioration when added in a concentration of $50 \%$; lower concentrations were not so effective.

Filtration. Haemagglutinin was almost completely absorbed during filtration through Seitz filters. Treatment of the filter pad with $50 \%$ rabbit serum and phosphate buffer (Evans \& Maitland, 1937) before filtration did not reduce the absorptive capacity of the filter for haemagglutinin. Filtration through Gradocol filters, however, proved to be successful as only a slight loss in activity occurred.

\section{HAEMAGGLUTININ IN RELATION TO IMMUNITY}

Active immunization of mice. Mice were immunized intraperitoneally with haemagglutinin preparations and challenged either intracerebrally or intranasally with living $\boldsymbol{H}$. pertussis. Six different preparations of methanolprecipitated haemagglutinin were tested. They were first dissolved in phosphate buffer to give a titre of $1 / 128$ and then absorbed on to R.B.c. This adsorption was repeated with fresh batches of extracts until the cells were saturated with haemagglutinin and unable to absorb further amounts. A $10 \%$ suspension of the R.B.c. was then made and was calculated from tests on the haemagglutinin solutions before and after absorption to contain about 4000 m.h.u./ml. Three groups of mice, fifteen in each group, were injected intraperitoneally with the R.в.c. antigen. The dose for the first group was $1.0 \mathrm{ml}$., for the second $0.75 \mathrm{ml}$. and for the third $0.5 \mathrm{ml}$. The injections were repeated 5 days later, and after 10 days each mouse was challenged intracerebrally according to the method of Kendrick, Updyke \& Eldering (1949) with approximately $200 \mathrm{LD} 50$ of living $H$. pertussis. The results are given in Table 6 , and it is evident that little or no protection was produced by any of the preparations when compared with that given by a control bacterial vaccine.

Similar results were also obtained (Table 6) when the intranasal challenge route was used.

Passive immunization of mice. Antihaemagglutinin was prepared in rabbits using haemagglutinin absorbed on to R.B.c. The antiserum which had an antihaemagglutinin titre of $1 / 1200$ was tested for its ability to protect mice against pertussis infection. A mixture of equal parts of undiluted antiserum and a suspension of $H$. pertussis was made to contain $2500 \times 10^{6}$ organisms $/ \mathrm{ml}$. The mixture was inoculated intranasally into mice (Evans, 1944), and each animal received approximately $0.05 \mathrm{ml}$. which contained $100 \times 10^{6}$ organisms equivalent to $100 \mathrm{LD} \mathrm{50.} \mathrm{Results} \mathrm{are} \mathrm{given} \mathrm{in} \mathrm{Table} 7$ and it is evident that the antiserum showed little or no protective property. In other experiments (Table 7) the antiserum was given intraperitoneally $4 \mathrm{hr}$. before the mice were challenged by intracerebral injection. Again there was little evidence that the antihaemagglutinin serum was able to protect against infection. In this experiment antiserum prepared against whole organisms was also tested and gave substantial protection. 
Table 6. Active immunization of mice with purified haemagglutinins adsorbed on erythrocytes

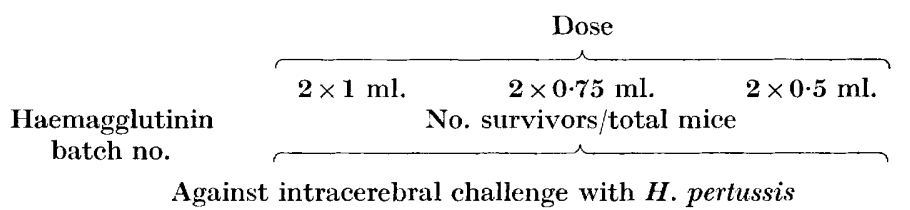

$\begin{array}{crrr}1 & 3 / 12 & 4 / 15 & 1 / 11 \\ 2 & 2 / 11 & 2 / 15 & 3 / 15 \\ 3 & 2 / 11 & 2 / 11 & 1 / 13 \\ 4 & 3 / 15 & 0 / 11 & 2 / 14 \\ 5 & 1 / 15 & 2 / 15 & 1 / 15 \\ 6 & 4 / 15 & 3 / 14 & 2 / 11 \\ \text { Total } & 15 / 79 & 13 / 81 & 10 / 79 \\ \text { bacterial vaccine* } & 51 / 80 & 30 / 80 & 19 / 76\end{array}$

Control bacterial vaccine* $\quad 51 / 80 \quad 30 / 80 \quad 19 / 76$

Control unimmunized mice $\quad 3 / 88$

\begin{tabular}{crrr}
\multicolumn{5}{c}{ Against intranasal challenge with $H$. pertussis } \\
1 & $3 / 15$ & $2 / 15$ & $2 / 12$ \\
2 & $2 / 13$ & $3 / 15$ & $3 / 14$ \\
3 & $2 / 15$ & $1 / 15$ & $3 / 15$ \\
4 & $2 / 15$ & $4 / 15$ & $3 / 15$ \\
5 & $3 / 14$ & $0 / 15$ & $5 / 15$ \\
6 & $4 / 15$ & $1 / 13$ & $0 / 14$ \\
Total & $16 / 87$ & $11 / 88$ & $15 / 85$ \\
Control bacterial vaccine* & $44 / 77$ & $31 / 84$ & $16 / 81$
\end{tabular}

Control unimmunized mice $12 / 90$

* Doses, control bacterial vaccine: $1 \times 0.2 \mathrm{ml}$., $1 \times 0.04 \mathrm{ml}$., $1 \times 0.008 \mathrm{ml}$. of a vaccine containing $10,000 \times 10^{6} / \mathrm{ml}$.

Table 7. Passive protection of mice rith sera prepared in rabbits against purified haemagglutinins adsorbed on erythrocytes

Anti-

haemagglutinin Average time

Serum no. $\quad$ No. protected/total mice to death (days)

Serum and challenge dose of $\boldsymbol{H}$. pertussis mixed and given intranasally

$\begin{array}{lrrr}1 & 1200 & 1 / 13 & 4 \cdot 58 \\ 2 & 600 & 1 / 14 & \mathbf{5 \cdot 6 9} \\ 3 & 1200 & 3 / 10, \quad 2 / 15, \quad 3 / 15=8 / 40 & 5 \cdot 15 \\ 4^{*} & <2 & 2 / 10,2 / 15,2 / 15-6 / 40 & 5 \cdot 84 \\ 5 \dagger & & 9 / 10,13 / 15,13 / 15=35 / 40 & \end{array}$

Serum given intraperitoneally $4 \mathrm{hr}$. before intracerebral challenge

$\begin{array}{rrlr}6 & 1400 & 3 / 7,2 / 10,1 / 10=6 / 27 & 7 \cdot 3 \\ 7 & 600 & 3 / 8, \quad 0 / 10,3 / 10=6 / 28 & 7 \cdot 1 \\ 4^{*} & <2 & 0 / 10,2 / 9,0 / 10=2 / 29 & 6 \cdot 1 \\ 5 \dagger & 10 & 9 / 10,10 / 10,5 / 10=24 / 30 & 10 \cdot 4\end{array}$

* Normal rabbit serum.

$\dagger$ Immune rabbit serum prepared against living $\boldsymbol{H}$. pertussis cells. 


\section{CONCLUSIONS}

These experiments have shown that the haemagglutinin of $\boldsymbol{H}$. pertussis can be extracted from the bacillus by sodium acetate and concentrated by absorption on to fowl erythrocytes. This preparation was free from the bacterial agglutinogen and toxin, and thus it was possible to study the protective properties of haemagglutinin alone. It is evident from the results that the purified haemagglutinin was unable to induce an active immunity to experimental pertussis infection in mice and that antiserum with a high content of antihaemagglutinin gave no passive protection. These results suggest that although haemagglutinin is antigenically active it is not of importance in the control of experimental infection.

These results are not, however, in agreement with those of Keogh \& North who expressed the opinion that haemagglutinin was able to induce protection against experimental infection. The antigen they used in their experiments was not, however, free from other antigens of $\boldsymbol{H}$. pertussis and did in fact contain the bacterial agglutinogen.

These results are in agreement with those recently obtained by Pillemer (1950), who has prepared a protective antigen from ultrasonic extracts of $\boldsymbol{H}$. pertussis and says that this antigen did not contain any haemagglutinin.

This work formed part of a thesis approved by the University of London for the award of a Ph.D. Degree.

The author is indebted to the Director of the Lister Institute of Preventive Medicine for facilities provided to do the work and to Mr A. F. B. Standfast and Dr D. McClean for their interest, advice and guidance.

\section{REFERENCES}

Confen, S. M. \& Whezler, M. W. (1946). Pertussis vaccine prepared with phase I cultures grown in fluid medium. Amer. J. publ. Hlth, 36, 371.

Evans, D. G. (1944). The protective properties of pertussis anti-sera in experimental infection. J. Path. Bact. 56, 49.

Evans, D. G. \& MaItLand, H. B. (1937). The preparation of the toxin of $\boldsymbol{H}$. pertussis: its properties and relation to immunity. J. Path. Bact. 45, 715.

Fisher, S. (1948). The behaviour of $\boldsymbol{H}$. pertussis in casein hydrolysate broth. Aust. J. exp. Biol. med. Sci. 26, 299.

Flosdort, E. W. \& Krmball, A. C. (1940). Comparison of various physical means of liberation of agglutinogen of $\boldsymbol{H}$. pertussis phase I. J. Immunol. 39, 287.

Hink, J. H. \& Johnson, F. F. (1947). Preparation of an antigen mixture of $\boldsymbol{H}$. pertussis by selective denaturation. J. Immunol. 57, 323.

Katasampes, C. P., Brooks, A. M. \& Bradford, W. L. (1942). Toxicity of washings from Hemophilus pertussis for mice. Proc. Soc. exp. Biol., N.Y. 49, 615.

Kendrick, P. L., Updyke, E. L. \& Eldering, G. (1949). Comparison of pertussis cultures by mouse protection and virulence tests. Amer. J. publ. Hlth, 39, 179.

Keogh, E. V. \& North, E. A. (1948). The haemagglutinin of $\boldsymbol{H}$. pertussis. 1. Haemagglutinin as a protective antigen in experimental murine pertussis. Aust. J. exp. Biol. med. Sci. 26, 315.

Lawson, G. M. (1940). Modified technique for staining capsules of Haemophilus pertussis. J. Lab. clin. Med. 25, 435. 
McIlwain, H. (1948). Preparation of cell free bacterial extracts with powdered alumina. J. gen. Microbiol. 2, 288.

Mrller, J. J. (1934). Experimental observations on the antigenic potency of H. pertussis extracts. J. Immunol. 26, 247.

Murray, E. G. D. (1929). The Meningococcus. Spec. Rep. Ser. med. Res. Coun., Lond. no. 124.

Pillemer, L. (1946). The immunochemistry of toxins and toxoids. 1. The solubility and precipitation of tetanol toxin and toxoid in methanol-water mixture under controlled conditions of $\mathrm{pH}$, ionic strength and temperature. J. Immunol. $53,237$.

Pillemer, L. (1950). Adsorption of protective antigen of $\boldsymbol{H}$. pertussis on human red cell stromata. Proc. Soc. exp. Biol., N.Y. 75, 704.

Pillemer, L., Toll, D. \& Badger, S. J. (1947). Immunochemistry of toxins and toxoids. III. Isolation and characterisation of diphtherial toxoid. J. biol. Chem. 170, 571 .

Robins, K. C. \& Prllemer, L. (1950). The separation of a protective antigen from a toxin-producing strain of Hemophilus pertussis. J. Immunol. 65, 393.

SALK, J. E. (1944). A simplified procedure for titrating haemagglutinating capacity of influenza virus and the corresponding antibody. J. Immunol. 49, 87.

Smolens, J. \& Mudd, S. (1943). Agglutinogen of Haemophilus pertussis, Phase 1, for skin-testing. Theoretical consideration, and a simple method of preparation. J. Immunol. 47, 155.

Standfast, A. F. B. (1951a). The virulence of Haemophilus pertussis for mice by the intranasal route. J. gen. Microbiol. 5, 250.

Standfast, A. F. B. (1951 b). The phase 1 of Haemophilus pertussis. J. gen. Microbiol. $5,531$.

Ungar, J. (1949). Agglutination of red blood cells by H. pertussis. J. Path. Bact. 61, 140 . 